\title{
Effect of Compost Amendment or Straw Mulch on Potato Early Dying Disease
}

\author{
J. A. LaMondia, Department of Plant Pathology and Ecology, Connecticut Agricultural Experiment Station, P.O. \\ Box 248, Windsor 06095; M. P. N. Gent, Department of Forestry and Horticulture, F. J. Ferrandino and W. H. \\ Elmer, Department of Plant Pathology and Ecology, and K. A. Stoner, Department of Entomology, Connecticut \\ Agricultural Experiment Station, New Haven 060504
}

\begin{abstract}
LaMondia, J. A., Gent, M. P. N., Ferrandino, F. J., Elmer, W. H., and Stoner, K. A. 1999. Effect of compost amendment or straw mulch on potato early dying disease. Plant Dis. 83:361-366.

Single potato plants (Solanum tuberosum) cv. Superior were grown in field microplots to evaluate the effects of spent mushroom compost or straw mulch on early dying of potato caused by Verticillium dahliae and/or Pratylenchus penetrans. Prior to planting, soil was fumigated, placed in field microplots, and then infested with pathogens. Area under the senescence progress curve (AUSPC) was greater for plots infested with $V$. dahliae and/or P. penetrans than for noninfested plots. Plants grown in soil infested with both pathogens developed symptoms earlier than plants grown in soil infested with a single pathogen. Both $V$. dahliae and $P$. penetrans reduced yields; the combination of pathogens reduced marketable tuber yields by 22 to $44 \%$ (A- and B-sized tubers). Although the total number of tubers of all sizes was not affected by cultural or pathogen treatments, the addition of compost increased marketable tuber weight and decreased AUSPC. Soil amendment with spent mushroom compost may be a means of reducing the effects of potato early dying and increasing tuber yield when one or both pathogens are present.
\end{abstract}

Additional keywords: lesion nematode, Verticillium wilt

The early dying syndrome of potatoes (Solanum tuberosum L.) results in premature vine senescence and can limit tuber yield by 30 to $50 \%(33,34)$. Early dying is primarily caused by the vascular wilt pathogen Verticillium dahliae Kleb., but coinfection of potato by $V$. dahliae and the lesion nematode Pratylenchus penetrans (Cobb) Filipjev \& Schuur.-Stek. can increase both the severity of disease and tuber losses $(22,26,34)$.

Soil fumigation is the primary means of managing this disease, but cost may limit its use $(31,34)$. A number of nonchemical controls are under development, but each currently has limitations. A 5- to 10-year rotation is required to reduce $V$. dahliae density in soil (9). Verticillium-resistant cultivars are under development but are not widely accepted commercially (23). Irrigation and nutrient management may reduce the development of disease in a crop, but other cultural practices need to be integrated with these to increase efficacy $(5,6)$. Additional alternative practices include soil amendments and mulches. The addition of compost to soil can reduce diseases caused by soilborne fungi $(21,38)$ and in-

Corresponding author: J. A. LaMondia

E-mail: lamondia@caes.state.ct.us

Accepted for publication 15 December 1998.

Publication no. D-1999-0125-02R

(C) 1999 The American Phytopathological Society crease water-holding and ion-exchange capacity of the soil (27). Maynard (27) noted that eggplant yield in compostamended plots did not decline as rapidly from Verticillium wilt as it did in nonamended plots that were nutritionally balanced with conventional fertilizers. The addition of organic matter to potato fields also was associated with reduced populations of Pratylenchus spp. $(10,16)$.

This research was done as part of an integrated pest and pathogen management project for control of Colorado potato beetle and early dying. A straw mulch was useful in suppressing Colorado potato beetles and may also conserve soil moisture and reduce soil temperatures (36). High temperatures and excessive moisture early in the season, or drought during tuber filling, have been associated with increased early dying disease and reduced yields $(5,17,19,30)$. The indirect effects of straw on early dying were not previously investigated.

The objectives of our research were to determine the effects on potato early dying of amending mineral soil with either spent mushroom compost or surface-applied straw mulch. Additionally, we evaluated the interactions of $V$. dahliae and $P$. penetrans on Superior potatoes in microplots, the influence of spent mushroom compost or straw mulch on the development of senescence due to potato early dying, and the effects of these variables on potato yield. A companion paper describes the effects of disease and cultural treatments on potato gas exchange under field conditions (20).

\section{MATERIALS AND METHODS}

Microplots were established in Windsor, Connecticut, in 1992. They consisted of plastic waste cans $(37.5-\mathrm{cm}$ top diameter, $30-\mathrm{cm}$ bottom diameter, and $45 \mathrm{~cm}$ deep, open at the bottom) buried in soil to within $10 \mathrm{~cm}$ of the top and filled with fumigated loamy sand field soil (78.0\% sand, $16.9 \%$ silt, $5.1 \%$ clay $[\mathrm{pH} 5.6], 2.8 \%$ organic matter). In April 1992, 2 weeks prior to filling microplots, the soil was fumigated with methyl-bromide $\left(0.45 \mathrm{~kg}\right.$ a.i. $/ 72 \mathrm{~m}^{2}$, $20 \mathrm{~cm}$ deep between sheets of plastic). In 1992, 60 microplots were placed on 0.9-m centers in three rows spaced $1.2 \mathrm{~m}$ apart. An additional 60 microplots were added in 1994 in three extra rows. Soil was fumigated as before and added to the microplots. All microplots were fumigated once prior to pathogen inoculation. Pathogen populations were naturally maintained over the length of the experiment. All operations that could potentially result in cross-contamination of soil in plots, such as the incorporation of compost, planting, sampling, and harvesting, were done with disposable equipment, or equipment was cleaned and surface-sterilized with $0.5 \%$ $\mathrm{NaOCl}$ between microplots.

There were 12 treatments: four pathogen treatments (no pathogen, V. dahliae alone, $P$. penetrans alone, and both $V$. dahliae and $P$. penetrans) and three cultural treatments (compost, straw, and conventional). These treatments were applied in a factorial design that was replicated five times in 1992 and 1993 and 10 times in 1994 and 1995.

Inoculum of $V$. dahliae microsclerotia was prepared by adding $150 \mathrm{ml}$ of a $48-\mathrm{h}$ shake culture of $V$. dahliae in potato-infusion sucrose broth $(60 \mathrm{~g}$ of potato per liter of water autoclaved and filtered, plus $8 \mathrm{~g}$ of sucrose per liter) to $300 \mathrm{~cm}^{3}$ of a $1: 1$ mix of pasteurized field soil and dry unprocessed wheat bran. The soil and bran mix had previously been autoclaved three times on successive days. The fungus was allowed to colonize the mix under sterile conditions for 2 weeks and was slowly airdried at room temperature after microsclerotia had formed. V. dahliae microsclerotia inoculum (11.5 g per microplot) from a bran/soil culture or a sterile bran/soil mix (control) was added to soil and incorporated into approximately 20 liters of topsoil per microplot with a trowel.

$P$. penetrans inoculum $(20,000$ eggs, juveniles, and adults) extracted from monox- 
enic carrot disk culture, or the suspension resulting from a similar extraction from carrot disks without nematodes, was added to plots $2.5 \mathrm{~cm}$ below the tubers at planting. This nematode culture was originally recovered from sour cherry roots in New York.

Spent mushroom compost (2.7 liters per plot, Franklin Mushroom Farms, Franklin, CT) was added to the top of appropriate microplots (approximately $2.5 \mathrm{~cm}$ in depth = 15 metric tons/ha) and incorporated with a small shovel. The compost had been derived primarily from horse manure and bedding, and was composted for 6 months outdoors in static piles that were turned monthly (27). The spent mushroom compost had a density when dry of $50 \mathrm{~kg} / \mathrm{m}^{3}$, a $\mathrm{pH}$ of 7.3, and $\mathrm{N}, \mathrm{P}$, and $\mathrm{K}$ percentage values of 0.6, 1.0, and 1.5. Rye straw mulch was applied to an 8-cm depth around plants after fertilizing and pulling soil up around plants to simulate hilling. Dates of cultural and experimental procedures are presented in Table 1.

Certified B-sized seed potatoes (Superior) were planted 5 to $8 \mathrm{~cm}$ below the soil surface in the microplots (one tuber per microplot), between each microplot within rows, and in border rows $(20-\mathrm{cm}$ spacing). All plots without compost were fertilized with $112 \mathrm{~kg}$ N/ha 5:10:10 (N:P:K) before planting and side-dressed with $56 \mathrm{~kg} \mathrm{~N} /$ ha 5:10:10 (Table 1). Plots amended with compost were fertilized with sufficient $\mathrm{N}: \mathrm{P}: \mathrm{K}$ to achieve the equivalent nutrient levels based on a preplant soil test by the Connecticut Agricultural Experiment Station soil test lab. Preplant soil $\mathrm{pH}$ was determined using a glass electrode $\mathrm{pH}$ meter. One core per plot $(2.5$ to $15 \mathrm{~cm}$ deep) was bulked over replications for each treatment. Preplant $\mathrm{pH}$ ranged from 5.5 to 5.8 in $1992,4.9$ to 5.7 in 1993 , and 5.6 to 6.0 in 1994. Soil pH increased after each season in compost plots. In 1995, the $\mathrm{pH}$ of nonamended plots was approximately 5.8, and the $\mathrm{pH}$ of compost plots was 6.6. To equalize the $\mathrm{pH}, 6 \mathrm{~g}$ of elemental sulfur was added to compost plots prior to planting in 1994 and 1995.

Colorado potato beetles and foliar diseases such as early or late blight were con-

Table 1. Timing of cultural or experimental procedures in field microplot potato early dying experiments: 1992 to 1995

\begin{tabular}{lcccc}
\hline Procedure & $\mathbf{1 9 9 2}$ & $\mathbf{1 9 9 3}$ & $\mathbf{1 9 9 4}$ & $\mathbf{1 9 9 5}$ \\
\hline Fumigation & $4 / 29$ & & $4 / 14$ & \\
Fertilization & $5 / 19$ & $4 / 29$ & $5 / 5$ & $5 / 9$ \\
Compost added & $5 / 19$ & $4 / 30$ & $5 / 5$ & $5 / 5$ \\
Pathogens added & $5 / 21$ & & $5 / 5$ & \\
Planting & $5 / 22$ & $4 / 30$ & $5 / 5$ & $5 / 9$ \\
Herbicide application & $5 / 22$ & $5 / 3$ & $5 / 6$ & $5 / 9$ \\
Hilling/cultivation & $6 / 18$ & $5 / 25$ & $6 / 22$ & $6 / 16$ \\
Straw mulch added & $6 / 23$ & $6 / 2$ & $6 / 22$ & $6 / 22$ \\
Fertilizer sidedress (5:10:10) & $7 / 7$ & $6 / 21$ & $6 / 7 \& 6 / 22$ & $6 / 16 \& 7 / 6$ \\
Sidedress rate(s) kg N/ha & 56 & 56 & $28 \& 28$ & $28 \& 28$ \\
Number of weekly disease & 7 & 4 & 8 & 8 \\
$\quad$ evaluations & & & & \\
Harvest date & $9 / 4$ & $8 / 23$ & $9 / 6$ & $8 / 24$ \\
Rye seeded & $9 / 8$ & $8 / 24$ & $9 / 9$ & $9 / 14$ \\
Pathogens sampled & $11 / 5$ & $11 / 23$ & $11 / 22$ & $11 / 13$ \\
Number of insecticide & 9 & 7 & 10 & 4 \\
or fungicide applications & & & & \\
\hline
\end{tabular}

trolled by weekly applications of insecticides and fungicides as necessary. Insecticides used included Asana XL (0.7 liters/ha), Thiodan 3EC (3.0 liters/ha), Imidan 50W (2.2 kg/ha), Sevin 50W (2.2 $\mathrm{kg} / \mathrm{ha}$ ) and Admire 2F (used in 1995 on border plants at 0.9 liters/ha). Bravo 500 (2.3 liters/ha) and Manzate D (2.2 kg/ha) were rotated in combination with insecticides.

Overhead irrigation (approximately 2.5 $\mathrm{cm}$ ) was applied when less than $2.5 \mathrm{~cm}$ of rain fell in the preceding week, and plots were lightly irrigated to cool the plants when air temperatures were greater than $30^{\circ} \mathrm{C}$.

Plants were evaluated weekly for up to 8 weeks starting with the first symptoms of senescence and continuing until almost all plants had died. The number of live or dead stems and the number of compound leaves with or without chlorosis or wilt symptoms were counted weekly for 7 weeks in 1992, 4 weeks in 1993, and 8 weeks in 1994 and 1995 for each microplot. The ratio of symptomatic leaves to maximum number of leaves and the ratio of dead stems to total number of stems were integrated over the length of the epidemic and expressed as area under the senescence progress curve (AUSPC). Plants were not destructively sampled to recover $V$. dahliae, but microsclerotia were associated with senescent stems on earlysenescing plants. $V$. dahliae was recovered from similar stems after destructive sampling in other experiments (13).

Plots were harvested after the vines had died. Tubers were dug with a forked spade, graded for size, and weighed. Grade Asized tubers were greater than $5 \mathrm{~cm}$ in diameter, grade B-sized tubers were between 3.8 and $5 \mathrm{~cm}$, and culls were less than $3.8 \mathrm{~cm}$ in diameter. A- and B-sized tubers constituted marketable yield, and all tubers, regardless of size, were included in total yield. After harvest, plots were seeded

Table 2. Effect of compost amendment or straw mulch on area under the senescence progress curve (AUSPC) values for percent early dying-symptomatic leaves and stems of Superior potatoes in field microplots infested with Verticillium dahliae and/or Pratylenchus penetrans

\begin{tabular}{|c|c|c|c|c|c|c|c|c|}
\hline & \multicolumn{4}{|c|}{ AUSPC for percent symptomatic leaves } & \multicolumn{4}{|c|}{ AUSPC for percent symptomatic stems } \\
\hline & 1992 & 1993 & 1994 & 1995 & 1992 & 1993 & 1994 & 1995 \\
\hline \multicolumn{9}{|l|}{ Culture $^{\mathrm{a}}$} \\
\hline None & 15.6 & 8.4 & 10.5 & 24.5 & 6.3 & 1.3 & 6.8 & 9.2 \\
\hline Compost & 10.9 & 6.8 & 9.8 & 14.7 & 3.8 & 1.1 & 4.6 & 3.8 \\
\hline Straw & 15.8 & 8.3 & 10.7 & 23.8 & 7.3 & 1.2 & 7.9 & 9.2 \\
\hline \multicolumn{9}{|l|}{ Pathogens ${ }^{b}$} \\
\hline$V d-P p-$ & 9.9 & 7.0 & 5.8 & 16.2 & 0.2 & 1.2 & 2.0 & 1.5 \\
\hline$V d-P p+$ & 11.8 & 5.9 & 9.3 & 19.8 & 1.8 & 1.0 & 5.6 & 5.9 \\
\hline$V d+P p$ & 17.4 & 8.5 & 10.9 & 22.4 & 9.2 & 1.4 & 6.5 & 9.0 \\
\hline$V d+P p+$ & 17.2 & 9.7 & 15.7 & 25.6 & 11.7 & 1.3 & 12.1 & 13.1 \\
\hline \multicolumn{9}{|l|}{ Factor $(P=)$} \\
\hline Culture & 0.0001 & $\mathrm{NS}^{\mathrm{c}}$ & NS & 0.0001 & 0.02 & NS & NS & 0.0001 \\
\hline V. dahliae & 0.0001 & 0.005 & 0.0001 & 0.0001 & 0.0001 & NS & 0.0001 & 0.0001 \\
\hline$P$. penetrans & NS & NS & 0.0001 & 0.0001 & 0.04 & NS & 0.0001 & 0.0001 \\
\hline$V d^{*} P p$ & NS & NS & NS & NS & NS & NS & NS & NS \\
\hline
\end{tabular}

${ }^{a}$ Mineral soil alone, amended with incorporated spent mushroom compost or surface-applied straw mulch.

${ }^{\mathrm{b}}$ With or without Verticillium dahliae (Vd) or Pratylenchus penetrans $(P p)$ in a factorial design.

${ }^{\mathrm{c}}$ Not significant. 
with a standard rye cover crop $\left(20 \mathrm{~cm}^{3}\right.$ of seed per plot). Because vines died over a period of up to 4 weeks, and nematode recovery efficiencies differ markedly from roots and soil, nematodes were recovered from roots of the rye cover crop to allow comparison between plots. Four subsamples of rye were removed per plot in the fall. Roots were shaken and washed free of soil, and $P$. penetrans was extracted from 2 $\mathrm{g}$ of root per plot on a rotary arm shaker over 10 days. Remaining soil was air-dried and assayed for $V$. dahliae by plating diluted soil on ethanol-streptomycin agar (29).

\section{RESULTS}

The addition of spent mushroom compost decreased AUSPC in the 2 years when early dying was most severe, 1992 and 1995 (Table 2, Figs. 1 and 2). There was no interaction for effects of cultural amendments and pathogens on symptom development, AUSPC, number of stems or leaves, or on tuber yield. Plants grown in compost-amended plots had greater numbers of leaves in the 2 years in which AUSPC were not different between cultural treatments. Numbers of stems were not affected by cultural treatments in 3 of the 4 years (data not shown). Plant size as determined by maximum number of leaves was not affected by either pathogen alone or in combination (data not shown). The presence or absence of $V$. dahliae and $P$. penetrans influenced leaf symptom development (Fig. 3, Table 2). AUSPC for both leaf symptoms and stem symptoms (Table 2) was greater in plots infested with $V$. dahliae than in noninfested plots. P. penetrans increased leaf symptoms of early senescence in 2 years of the 4-year study. Onset of symptoms first occurred on 7 July 1993, 8 July 1994, and 5 July 1995. Leaf symptom incidence greater than $10 \%$ first occurred on 14 July 1993, 21 July 1994, and 14 July 1995 (19, 21, and $11 \%$, respectively).

Marketable tuber yield was much greater in compost-amended plots than in nonamended or straw mulched plots, which were not different (Table 3). Marketable tuber yields were reduced by both pathogens. V. dahliae reduced yields by $27 \%, P$. penetrans reduced yields by $12 \%$, and combined pathogens reduced marketable yields by an average of $34 \%$ over the 4 years of the experiment. The total number of tubers of all sizes was not affected by either culture or pathogens (data not shown), but the number of A-sized tubers was greater for compost-amended plots than for others and was decreased in the presence of either or both pathogens (Table 4).

The number of $P$. penetrans recovered from compost-amended plots was lower than from nonamended or straw mulched plots (Table 5). In 2 of the 4 years, $P$. penetrans populations were reduced in the presence of $V$. dahliae. The range in $V$. dahliae populations, as determined by soil dilution plating, was from 1 to $33 \mathrm{CFU} / \mathrm{g}$ of soil. Populations tended to increase over time but were variable across treatments (data not shown).

\section{DISCUSSION}

Our objectives were to determine the effects of either soil amendment with spent mushroom compost or surface-applied straw mulch on early dying of potato. In previous studies, the application of a straw mulch to potatoes increased yields in field plots in the presence of potato beetles and early dying pathogens, presumably due to effects on the behavior or survival of insects $(3,36,37)$. In the absence of beetle damage, we found no effect of straw mulch on early dying disease, nematodes, or tuber yield.
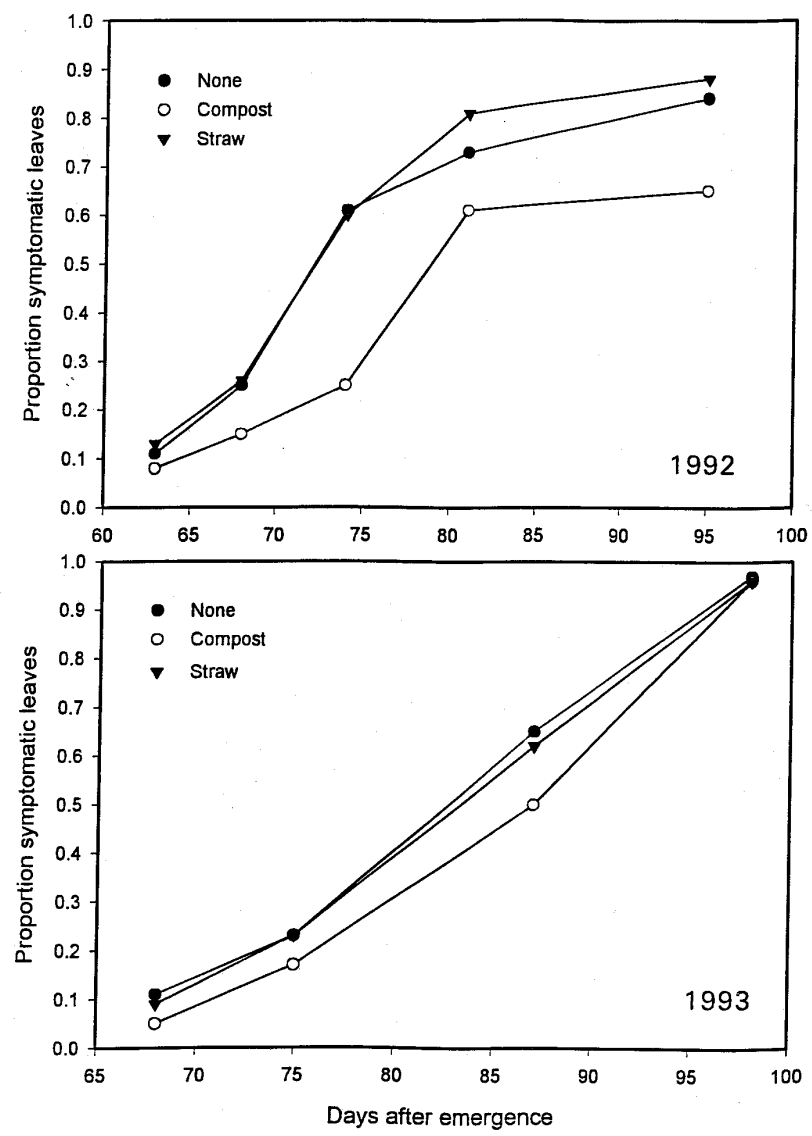

Fig. 1. Effect of no cultural amendment, compost amendment, or straw mulch on proportion of senescent leaves as a fraction of the maximum number of leaves on the plant. Data are averaged over pathogen treatments for 1992 and 1993.
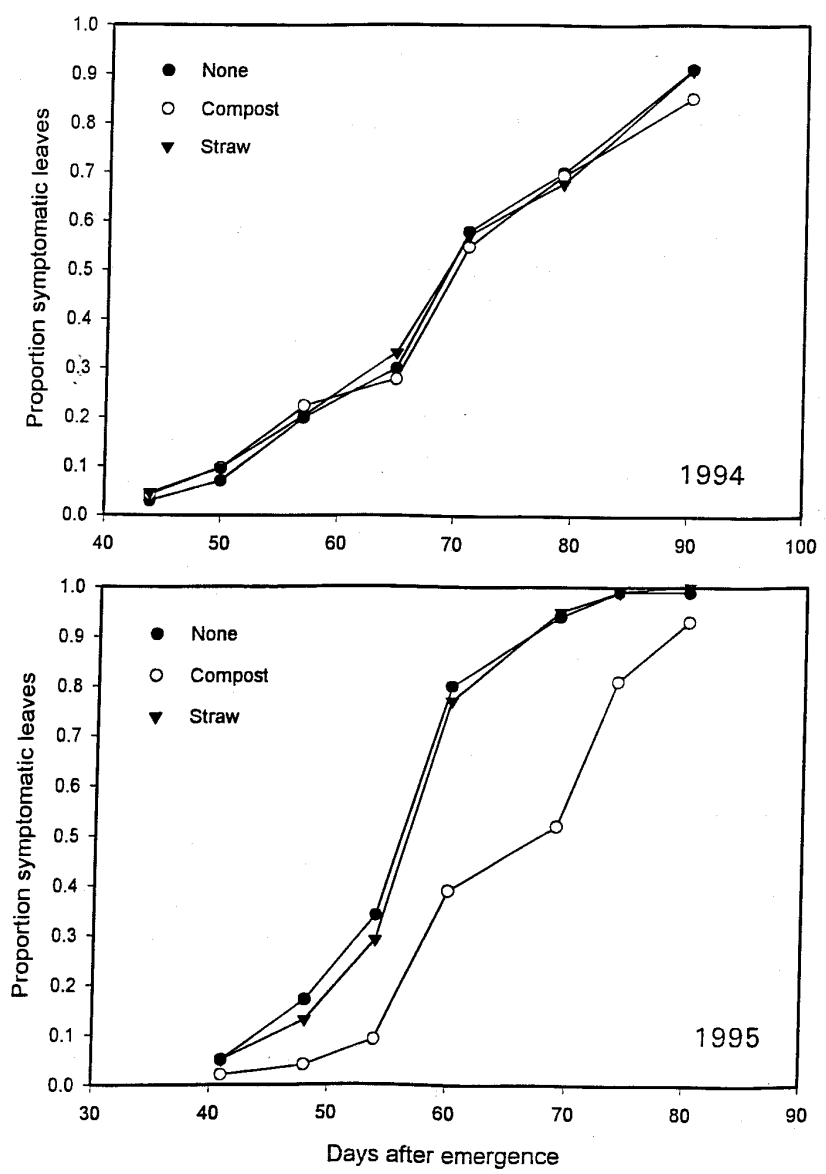

Fig. 2. Effect of no cultural amendment, compost amendment, or straw mulch on proportion of senescent leaves as a fraction of the maximum number of leaves on the plant. Data are averaged over pathogen treatments for 1994 and 1995. 
Soil amendment with spent mushroom compost reduced early dying disease severity and dramatically increased yields in our experiments. The same compost reduced yields of field plots when potatoes were defoliated by Colorado potato beetles $(13,36)$, presumably because the amendment resulted in a longer vegetative period prior to tuber initiation, and early defoliation reduced tuber size. A similar yield reduction due to delayed tuber initiation with compost might be expected for early dying, but it was not found in this study. Francl et al. (18) determined that soil type did not affect yield reduction due to potato early dying, only that yields were generally higher in organic soils than in mineral soils. We also found that tuber yields were increased in compost-amended mineral soils in our experiments. Symptoms of foliar senescence were delayed by up to 10 days in compost-amended plots. We also observed a delay in the decline of photosynthesis over time in compost-amended plots compared with nonamended plots (20). Pathogen populations or disease development may have been suppressed in compost-amended plots, but these effects were not large enough to result in a significant interaction between compost and pathogen treatments for AUSPC or yield data. $P$. penetrans populations were lower in compost-amended plots.

Tuber yield losses have previously been attributed to a reduction in both tuber size (24) and tuber number (1). In our experiments, losses were due to reduced size and a reduction in the number of large A-sized

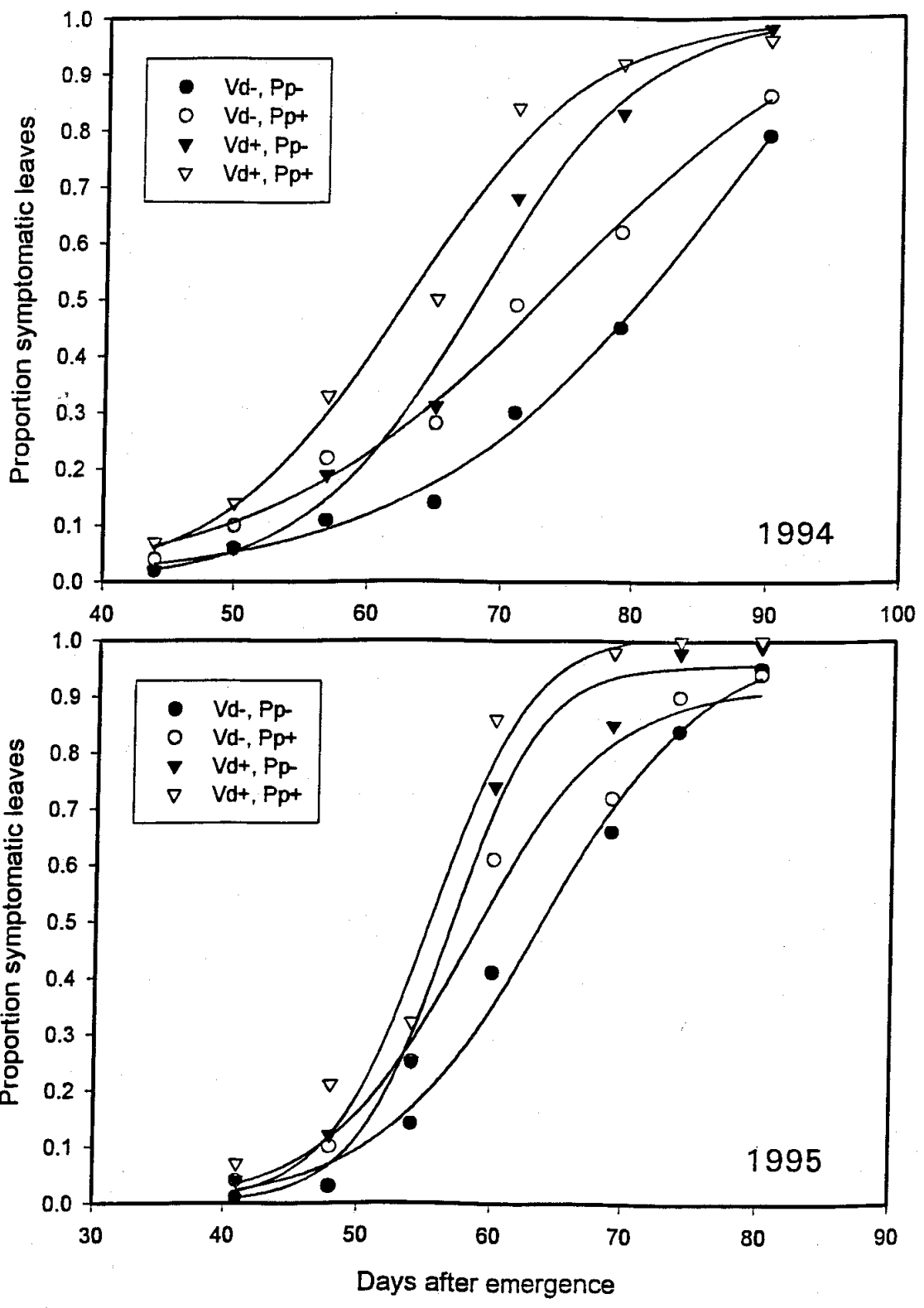

Fig. 3. Effect of Verticillium dahliae and/or Pratylenchus penetrans on proportion of senescent leaves as a fraction of the maximum number of leaves on the plant. Data are averaged over culture treatments for 1994 and 1995. tubers rather than a reduction in total tuber number. Chen et al. (7) reported that early dying resulted in an increased number of B-sized tubers at the expense of larger tubers. Yield losses in our experiments ranged from 32 to $56 \%$, similar to previously reported results $(26,32,35)$.

Nitrogen availability has been associated with potato early dying (34), and poor Nnutrition can result in increased disease (7). The addition of a balanced preplant and sidedress fertilizer was adjusted in spent mushroom compost-amended plots to equalize fertilization. However, the addition of compost to sandy soil may have resulted in direct effects that could not be controlled, including reduced leaching, better nitrogen availability, localized $\mathrm{pH}$ effects, or increased microbial competition and/or antagonism.

The combined effects of $V$. dahliae and $P$. penetrans in potato early dying have been reported to be synergistic $(2,35)$ or additive (22). Martin et al. (26) concluded that the interaction of these two pathogens was synergistic at low initial inoculum densities and additive at higher densities, when either pathogen alone caused disease and/or decreased yield. The statistical interaction which implies a synergistic interaction between the pathogens appears to depend on the lack of disease or yield loss at low initial inoculum densities. Regardless of pathogen density, and whether the effects were additive or synergistic, our results support the hypothesis that infection by both pathogens results in increased early dying and yield losses $(24,35)$.

Plants infested with both pathogens had an increased AUSPC because they developed symptoms earlier and declined more quickly than other plants. Both pathogens increased early season symptom development. Infestation with $V$. dahliae increased early dying in all 4 years. In 3 of 4 years, infestation with $P$. penetrans increased disease incidence on the dates when symptoms became evident and also when symptomatic leaves became more than $10 \%$ of the total leaves. The greatest amount of senescence generally occurs during the tuber bulking stage (24), consistent with our results.

The severity of potato early dying has been related to environmental conditions such as temperature and soil moisture. Francl et al. (17) determined that yield was correlated with number of days with mean temperatures greater than $24^{\circ} \mathrm{C}$, especially prior to tuber bulking. Increased soil water 3 to 5 weeks prior to tuber initiation also was associated with increased disease expression and reduced yields $(5,6)$. Temperatures in 1993, 1994, and 1995 were slightly higher than average. Rainfall was higher than average in 1992 and 1994, and lower than average in 1993 and 1995. Our weather and yield data are consistent with previous environmental observations and 
yield effects (17), and may partially explain the low severity of early dying present in our microplots in 1993. Only 2 days in June 1993 were warmer than $24^{\circ} \mathrm{C}$, and rainfall was lower than average, not resulting in excess soil moisture prior to tuber bulking. In the other 3 years, either high temperatures, excess soil moisture, or both were present in addition to the pathogens, contributing to the development of disease.

$V$. dahliae infection and early dying development in potato has had inconsistent effects on $P$. penetrans populations. In some cases, nematode populations were reduced after early plant senescence $(4,26,32)$, while there was no effect in others (24). Conroy et al. (8) observed a decrease in Pratylenchus populations in Verticillium-infected tomatoes. Others have

Table 3. Effect of compost amendment or straw mulch on marketable tuber yield (A- and B-sized tubers) of Superior potatoes in field microplots infested with Verticillium dahliae and/or Pratylenchus penetrans

\begin{tabular}{lcccc}
\hline & \multicolumn{4}{c}{ Marketable tuber yield (g) per microplot (single hill) } \\
\cline { 2 - 5 } & $\mathbf{1 9 9 2}$ & $\mathbf{1 9 9 3}$ & $\mathbf{1 9 9 4}$ & $\mathbf{1 9 9 5}$ \\
\hline Culture $^{\mathrm{a}}$ & & & & \\
None & 411.3 & 673.6 & 686.3 & 581.4 \\
Compost & 659.4 & $1,603.4$ & $1,225.8$ & $1,142.3$ \\
$\quad$ Straw & 407.7 & 710.1 & 703.6 & 619.2 \\
Pathogens & & & & \\
$V d-P p-$ & 588.3 & $1,227.0$ & $1,040.2$ & 980.3 \\
$V d-P p+$ & 575.9 & $1,019.8$ & 954.6 & 778.6 \\
$V d+P p-$ & 477.9 & 800.6 & 742.1 & 744.4 \\
$V d+P p+$ & 329.1 & 950.0 & 692.5 & 620.4 \\
Factor $(P=)$ & & & & \\
Culture & 0.0001 & 0.0001 & 0.0001 & 0.0001 \\
$V$. dahliae & 0.0001 & $\mathrm{NS}$ & 0.0001 & 0.0001 \\
$P$. penetrans & 0.013 & 0.004 & 0.026 & 0.0001 \\
$V d^{*}$ Pp & 0.035 & $\mathrm{NS}$ & $\mathrm{NS}$ & $\mathrm{NS}$ \\
\hline
\end{tabular}

${ }^{\text {a }}$ Mineral soil alone, amended with incorporated spent mushroom compost or surface-applied straw mulch.

${ }^{\mathrm{b}}$ With or without Verticillium dahliae (Vd) or Pratylenchus penetrans $(P p)$ in a factorial design.

${ }^{\mathrm{c}}$ Not significant. Verticillium-infected tomato, eggplant (28), and maple (12). To reduce sampling variation due to differential densities of $P$. penetrans in soil or roots due to root health, we sampled nematodes from the rye cover crop following potatoes. In these ents, recovery of $P$. penetrans populations from $V$. dahliae-infested plots was reduced in 2 years and unaffected in the other 2 years. Compost-amended plots, however, had reductions in $P$. penetrans populations in 3 years, with a similar trend

Potato root growth and yields were reduced by high populations of $P$. penetrans in field and greenhouse studies (11), but in other studies, no direct effect of $P$. penetrans on disease or yield of Superior or Russet Burbank potatoes has been demonstrated in reported an increase in Pratylenchus in in the fourth year. microplot experiments (22,34). In our microplot experiments, $P$. penetrans alone reduced tuber yields, but at relatively high densities, approximately double the densities reported by Kotcon et al. (22). Also, the presence of sandy soils has been associated with increased nematode damage (25).

Mechanisms of the nematode-fungus interaction may extend beyond root wounding causing increased fungal ingress and are dependent on Pratylenchus species (32). Infection by each pathogen on physically separated mint roots increased disease severity in split-root experiments in mint (15). Emmanouil and Wood (14) induced resistance to Verticillium in tomato, peppers, and eggplant by injecting plants with various nutrients. Nematode feeding can change host physiology and nutrition status, which may be associated with disease severity (32).

Spent mushroom compost amendment altered the mineral composition of roots and leaves (13), perhaps affecting plant nutrition and altering the response to early dying pathogens. Elmer et al. (13) documented increased microbial densities in potato rhizospheres in compost-amended soils, which could also affect pathogen inoculum potential and result in general or specific suppression of disease (21). Successful disease control in ornamentals has been reported in containers and under field conditions. A number of factors may contribute to the role of compost in reducing disease and increasing yields. Spent mushroom compost may influence potato nutrition or physiology, the physical properties of soil, pathogen populations, microbial ecology in soil, antibiosis, and possible systemic-acquired-resistance in relation to potato early dying. The mechanism(s) of this suppression needs to be determined to best adapt compost amendment to practical field application.

Table 4. Effect of compost amendment or straw mulch on grade A tuber yield of Superior potatoes in field microplots infested with Verticillium dahliae and/or Pratylenchus penetrans

\begin{tabular}{|c|c|c|c|c|c|c|c|c|}
\hline & \multicolumn{8}{|c|}{ A-sized tuber weight (g) and number per microplot (single hill) } \\
\hline & \multicolumn{2}{|c|}{1992} & \multicolumn{2}{|c|}{1993} & \multicolumn{2}{|c|}{1994} & \multicolumn{2}{|c|}{1995} \\
\hline & g & no. & g & no. & g & no. & g & no. \\
\hline \multicolumn{9}{|l|}{ Culture $^{\mathrm{a}}$} \\
\hline None & 188.1 & 1.9 & 87.9 & 0.8 & 252.2 & 1.8 & 137.8 & 1.2 \\
\hline Compost & 457.0 & 4.0 & $1,174.1$ & 8.0 & 962.2 & 5.6 & 834.2 & 5.1 \\
\hline Straw & 196.4 & 2.0 & 152.9 & 1.3 & 246.4 & 1.9 & 148.9 & 1.3 \\
\hline \multicolumn{9}{|l|}{ Pathogens ${ }^{b}$} \\
\hline$V d-P p-$ & 393.7 & 3.6 & 713.3 & 4.9 & 618.6 & 3.9 & 557.4 & 3.8 \\
\hline$V d-P p+$ & 354.7 & 3.2 & 580.9 & 3.8 & 612.6 & 3.7 & 401.5 & 2.6 \\
\hline$V d+P p-$ & 248.0 & 2.3 & 223.8 & 1.7 & 421.4 & 2.7 & 317.6 & 2.2 \\
\hline$V d+P p+$ & 125.5 & 1.3 & 392.3 & 3.1 & 277.9 & 1.9 & 218.1 & 1.6 \\
\hline \multicolumn{9}{|l|}{ Factor $(P=)$} \\
\hline Culture & 0.0001 & 0.0001 & 0.0001 & 0.0001 & 0.0001 & 0.0001 & 0.0001 & 0.0001 \\
\hline V. dahliae & 0.0001 & 0.0001 & 0.04 & $\mathrm{NS}^{\mathrm{c}}$ & 0.01 & 0.01 & 0.0001 & 0.0001 \\
\hline P. penetrans & 0.013 & 0.02 & 0.02 & 0.005 & 0.04 & 0.05 & 0.003 & 0.0005 \\
\hline$V d^{*} P p$ & 0.035 & NS & NS & NS & NS & NS & NS & NS \\
\hline
\end{tabular}

${ }^{\text {a }}$ Mineral soil alone, amended with incorporated spent mushroom compost or surface-applied straw mulch.

${ }^{\mathrm{b}}$ With or without Verticillium dahliae (Vd) or Pratylenchus penetrans $(P p)$ in a factorial design.

${ }^{\mathrm{c}}$ Not significant. 
Table 5. Effect of compost amendment or straw mulch on Pratylenchus penetrans populations in rye roots following Superior potatoes in field microplots infested with Verticillium dahliae and/or Pratylenchus penetrans

\begin{tabular}{|c|c|c|c|c|}
\hline & \multicolumn{4}{|c|}{$P$. penetrans per g rye roots } \\
\hline & 1992 & 1993 & 1994 & 1995 \\
\hline \multicolumn{5}{|l|}{ Culture $^{a}$} \\
\hline None & 77.5 & 80.7 & 81.0 & 121.4 \\
\hline Compost & 53.3 & 19.2 & 38.3 & 86.8 \\
\hline Straw & 90.6 & 109.0 & 148.8 & 241.1 \\
\hline \multicolumn{5}{|l|}{ Pathogen ${ }^{b}$} \\
\hline$V d-P p-$ & 0.6 & 1.7 & 0.0 & 5.0 \\
\hline$V d-P p+$ & 214.7 & 193.3 & 195.0 & 240.5 \\
\hline$V d+P p-$ & 0.1 & 18.4 & 0.0 & 56.0 \\
\hline$V d+P p+$ & 79.7 & 65.0 & 162.3 & 297.5 \\
\hline \multicolumn{5}{|l|}{ Factor $(P=)$} \\
\hline Culture & $\mathrm{NS}^{\mathrm{c}}$ & 0.011 & 0.019 & 0.058 \\
\hline V. dahliae & 0.02 & 0.02 & NS & NS \\
\hline P. penetrans & 0.0001 & 0.0001 & 0.0001 & 0.0001 \\
\hline$V d^{*} P p$ & 0.03 & 0.003 & NS & NS \\
\hline
\end{tabular}

a Mineral soil alone, amended with incorporated spent mushroom compost or surface-applied straw mulch.

${ }^{\mathrm{b}}$ With or without Verticillium dahliae $(V d)$ or Pratylenchus penetrans $(P p)$ in a factorial design.

c Not significant.

\section{ACKNOWLEDGMENTS}

This research was supported in part by the Cooperative State Research Service, U.S. Department of Agriculture, under Agreement No. 92-341037121. The authors thank J. Canepa-Morrison, M. Short, and R. Horvath for technical assistance.

\section{LITERATURE CITED}

1. Botseas, D. D., and Rowe, R. C. 1994. Development of potato early dying in response to infection by two pathotypes of Verticillium dahliae and co-infection by Pratylenchus penetrans. Phytopathology 84:275-282.

2. Bowden, R. L., and Rouse, D. I. 1991. Effects of Verticillium dahliae on gas exchange of potato. Phytopathology 81:293-301.

3. Brust, G. E. 1994. Natural enemies in strawmulch reduce Colorado potato beetle populations and damage in potato. Biol. Contr. 4:163-169.

4. Burpee, L. L., and Bloom, J. R. 1978. The influence of Pratylenchus penetrans on the incidence and severity of Verticillium wilt of potato. J. Nematol. 10:95-99.

5. Cappaert, M. R., Powelson, M. L., Christensen, N. W., and Crowe, F. J. 1992. Influence of irrigation on severity of potato early dying and tuber yield. Phytopathology 82:1448-1453.

6. Cappaert, M. R., Powelson, M. L., Christensen, N. W., Stevenson, W. R., and Rouse, D. I. 1994. Assessment of irrigation as a method of managing potato early dying. Phytopathology 84:792-800.

7. Chen, J., Bird, G. W., and Mather, R. L. 1995. Impact of multi-year cropping regimes on Solanum tuberosum tuber yields in the presence of Pratylenchus penetrans and Verticillium dahliae. J. Nematol. 27(4S):654-660.

8. Conroy, J. H., Green, J. R., Jr., and Ferris, J. M. 1972. Interrelationship of Verticillium albo-atrum and root lesion nematode Pratylenchus penetrans in tomato root with controlled inoculum densities. Phytopathology 62:362-336.

9. Davis, J. R., and McDole, R. E. 1979. Influence of cropping sequences on soilborne populations of Verticillium dahliae and Rhizoctonia solani. Pages 399-405 in: Soil-Borne Plant Pathogens. B Schippers and W. Gams, eds. Academic Press, New York.

10. D'Errico, F. P., and DiMaio, F. 1980. Effets des boues residuaires compostees sur la culture et le developpement de la pedofaune associee a l'oeillet. Rev. Zool. Agric. 79:23-28.

11. Dickerson, O. J., Darling, H. M., and Griffin, G. D. 1964. Pathogenicity and population trends of Pratylenchus penetrans on potato and corn. Phytopathology 54:317-322.

12. Dwinell, L. D., and Sinclair, W. A. 1967. Effects of N, P, K, and inoculum density of Verticillium dahliae on populations of Pratylenchus penetrans in roots of American elm and sugar maple. Phytopathology 57:810. Ferrandino, F. J., and Gent, M. P. N. 1995. Effect of straw and compost on early dying and Colorado potato beetle of potato, 1994. Biol. Cult. Tests Control Plant Dis. 10:96.

14. Emmanouil, V., and Wood, R. K. S. 1981. Introduction of resistance to Verticillium dahliae and synthesis of antifungal compounds in tomato, pepper and eggplant by injecting leaves with various substances. Phytopathol. Z. 100:212-225.

15. Faulkner, L. R., Bolander, W. J., and Skotland, C. B. 1970. Interaction of Verticillium dahliae and Pratylenchus minyus in Verticillium wilt of peppermint: Influence of the nematode as determined by a double root

16. Florini, D. A., Loria, R., and Kotcon, J. B. 1987. Influence of edaphic factors and previous crops on Pratylenchus spp. population densities in potato. J. Nematol. 19:856-892.

17. Francl, L. J., Madden, L. V., Rowe, R. C., and Riedel, R. M. 1990. Correlation of growing season environmental variables and the effect of early dying on potato yield. Phytopathology 80:425-432.

18. Francl, L. J., Rowe, R. C., Riedel, R. M., and Madden, L. V. 1988. Effects of three soil types on potato early dying disease and associated yield reduction. Phytopathology 78:159-166.

19. Gaudrealt, S. M., Powelson, M. L., Christensen, N. W., and Crowe, F. J. 1995. Soil water pressure and Verticillium interactions on potato. Phytopathology 85:1542-1546.

20. Gent, M. P. N., LaMondia, J. A., Ferrandino, F. J. Elmer, W. H., and Stoner, K. A. The influence of compost amendment or straw mulch on the reduction of gas exchange in potato by Verticillium dahliae and Praty-
13. Elmer, W. H., Stoner, K. A., LaMondia, J. A., technique. Phytopathology 60:100-103. lenchus penetrans. Plant Dis. In press.

21. Hoitink, H. A. J., Stone, A. G., and Han, D. Y. 1997. Suppression of plant diseases by composts. HortScience 32:184-187.

22. Kotcon, J. B., Rouse, D. I., and Mitchell, J. E. 1985. Interactions of Verticillium dahliae, Colletotrichum coccodes, Rhizoctonia solani, and Pratylenchus penetrans in the early dying syndrome of Russet Burbank potatoes. Phytopathology 75:68-74.

23. Lynch, D. R., Kawchuk, L. M., Hachey, J., Bains, P. S., and Howard, R. J. 1997. Identification of a gene conferring high levels of resistance to Verticillium wilt in Solanum chacoense. Plant Dis. 81:1011-1014.

24. MacGuidwin, A. E., and Rouse, D. I. 1990 Role of Pratylenchus penetrans in the potato early dying disease of Russet Burbank potato. Phytopathology 80:1077-1082.

25. Mai, W. F., Brodie, B. B., Harrison, M. B. and Jatala, P. 1981. Nematodes. Compendium of Potato Diseases. W. J. Hooker, ed. American Phytopathological Society, St. Paul, MN.

26. Martin, M. J., Riedel, R. M., and Rowe, R. C. 1982. Verticillium dahliae and Pratylenchus penetrans: Interactions in the early dying complex of potato in Ohio. Phytopathology 72:640-644.

27. Maynard, A. A. 1994. Sustained vegetable production for three years using composted animal manures. Compost Sci. Util. 2:88-96.

28. Mountain, W. B., and McKeen, C. D. 1965. Effects of transplant injury and nematodes on incidence of Verticillium wilt of eggplant. Can. J. Bot. 43:619-624.

29. Nadakavuukaren, M. J., and Horner, C. E. 1959. An alcohol agar medium selective for determining Verticillium microsclerotia in soil. Phytopathology 49:527-528.

30. Powelson, M. L., Johnson, K. B., and Rowe, R. C. 1993. Management of diseases caused by soilborne pathogens. Pages 149-158 in: Potato Health Management. American Phytopathological Society, St. Paul, MN.

31. Powelson, R. L., and Carter, G. E. 1973. Efficacy of soil fumigants for control of Verticillium wilt of potatoes. Am. Potato J 50:162-167.

32. Riedel, R. M., Rowe, R. C., and Martin, M. J. 1985. Differential interactions of Pratylenchus crenatus, $P$. penetrans, and $P$. scribneri with Verticillium dahliae in potato early dying disease. Phytopathology 75:419-422.

33. Rouse, D. I. 1985. Some approaches to prediction of potato early dying disease severity. Am. Potato J. 62:187-193.

34. Rowe, R. C., Davis, J. R., Powelson, M. L., and Rouse, D. I. 1987. Potato early dying: Causal agents and management strategies. Plant Dis. 71:482-489.

35. Rowe, R. C., Riedel, R. M., and Martin, M. J. 1985. Synergistic interactions between Verticillium dahliae and Pratylenchus penetrans in potato early dying disease. Phytopathology 75:412-418.

36. Stoner, K. A., Ferrandino, F. J., Gent, M. P. N., Elmer, W. H., and LaMondia, J. A. 1996. Effects of straw mulch, spent mushroom compost, and fumigation on the density of Colorado potato beetles (Coleoptera: Chrysomelidae) in potatoes. J. Econ. Entomol. 89:1267-1280.

37. Zehnder, G. W., and Hough-Goldstein, J. 1990. Colorado potato beetle (Coleoptera:Chrysomelidae) population development and effects on yield of potatoes with and without straw mulch. J. Econ. Entomol. 83:1982-1987.

38. Zhang, W., Dick, W. A., and Hoitink, H. A. J. 1996. Compost-induced systemic acquired resistance in cucumber to Pythium root rot and anthracnose. Phytopathology 86:1066-1070. 